\title{
RESPONSE OF SWEET PEPPER PLANTS TO FERTILIZE BY DIFFERENT ORGANIC FERTILIZERS UNDER PROTECTED AGRICULTURE .

\author{
Shahein, M. M. ${ }^{1}$; H. A. Hassan ${ }^{1}$ and S. Abou-El-Hassan ${ }^{2}$ \\ 1- Vegetable Dept., Faculty of Agriculture, Cairo University, Egypt. \\ 2- Central Lab of Organic Agriculture, Agricultural Research Center, \\ Egypt.
}

\begin{abstract}
Plastic house experiment was conducted during the two successive seasons of 2013/2014 and 2014/2015, atorganic farm in El-Aiat district, Giza Governorate, Egypt.This study aims to evaluate the organic production of two hybrids of sweet (bell) pepper using different sources of organic fertilizers under plastic house conditions.Five sources of organic fertilizers (quail, turkey chicken, rabbit manures and compost)as recommended dose of nitrogen for sweet pepper were investigated on vegetative growth,nutritional content, yield component and fruit quality of twohybridsof sweet pepper (Bunjii red fruit and Shunghi yellow fruit).The experimental treatments were arranged in split plot design with three replicates, where two hybrids of sweet pepper treatments were adapted in the main plots while five types of organic fertilizers treatments were randomized in the subplots. Obtained results showed that using compost produced the highest values of plant height, N\% of bell pepper plants, as well asthe maximum early, total yield and fruit length. Applying compost and chicken manure produced the highest values of fruit weight, total soluble sold and vitamin $\mathrm{C}$ content of pepper fruits. Compost, chicken and turkey manure treatments gave the maximum number of leaves per plant and chlorophyll reading of pepper leaves,percent of $\mathrm{P}$ and $\mathrm{K}$ in plants,fruit diameter and number of fruits /plant. There were no significant differences among all organic fertilizer treatments infirmness of pepper fruits. Generally, Bunjii hybridwas superior in the most of tested parameters compared to Shunghi hybrid of pepper.
\end{abstract}

Keywords: Sweet pepper, Organic fertilizers, Manure, Compost, Organic production

\section{INTRODUCTION}

Intensive synthetic fertilizer usage in agriculture caused so many health problems andenvironmental pollution. To reduce and eliminate the adverse effects of synthetic fertilizers and pesticides on human health and environment, new agricultural practices were developed in the so-called organic agriculture, ecological agriculture or sustainable agriculture. (Aksoy, 2001; Chowdhury, 2004; Malgorzata and Georgios, 2008).

Organic farming products are becoming very necessary in today's world to manage ecosystem health and to impart related human health benefits, world over there is growing demand for organic products. The organic areas in the whole world reached to 37.5 million hectares; whereas the cultivated organic area in Egypt is about 82000 hectares (FiBL and IFOAM, 2014).

Sweet pepper (Capsicum annuum $L$ ) is a member of the solanaceous vegetables group. It is one of the most important, popular and favorite vegetable crops cultivated in Egypt for local market and exportation. The 
cultivated area from sweet and hot pepper for all seasons was about 95 thousand feddans(faddan $=0.4$ hectare), produced about 651 thousand tons on annual basis with an average of 6.8 tons/feddan (Ministry of Agriculture and Land Reclamation, 2013).

The organic fertilizers provide the nutritional requirements of plants. Additionally, they increase the microbial activity in soil, anion and cation exchange capacity, organic matter and carbon-content of soil. Organic fertilizers produce the yield and quality of agricultural crops in ways similar to inorganic fertilizers (Heeb et al., 2006; Liu et al., 2007; Tonfack et al., 2009).

Organic manure can serve as alternative practice to mineral fertilizers (Naeem et al., 2006) for improving soil structure (Dauda et al., 2008) and microbial biomass (Suresh et al., 2004). Organic manure plays a direct role in plant growth as a source of all necessary macro and micronutrients in available forms during mineralization (Nweke et al., 2013) and improves physical and chemical properties of soils (Chaterjee et al., 2005). AnantBahadur et al. (2006) pointed that organic matter plays an important role in the chemical behavior of several metals in soils throughout its active groups (fulvic and humic acids) which have the ability to retain the metals in complex and chelate forms.Concerning organic fertilizers, many investigators found that, application of organic fertilizer had a major effect on vegetative growth characters of sweet pepper (Abdel-El-Moez et al., 2001; Arancon et al., 2005; Ewulo et al., 2007), total yield (Salama and Zake, 2000; Shehata et al., 2004; Awodun et al., 2007; Huez-Lopez et al., 2011) and quality of sweet pepper plants (Amorand Del, 2007; Arafa and Shalabey, 2007; Szafirowska and Elkner, 2008).

The present work aimed to evaluate the organic production of two hybrids of bell pepper using different sources of organic fertilizers under plastic house conditions.

\section{MATERIALS AND METHODS}

The experiment was conducted into plastic house during the two successive seasons of 2013/2014 and 2014/2015, atorganic farm in El-Aiat district, Giza Governorate, Egypt, which was certified as an organically farm in conversion period.

Bell pepper seeds of two hybrids (Bunjii red fruit and Shunghi yellow fruit) were sown in the seedling trays, which were filled with peat moss and vermiculite 1:1 (v:v) under nursery of plastic house on 10 and20 of August in first and second seasons, respectively. The seedlings were transplanted in the soil of plastic house on 1 and 10 of October in first and second seasons, respectively.The experimental soil was analyzed according to FAO (1980) and presented in Table 1.

Table 1.Physical and chemical analyses of the experimental soil

\begin{tabular}{|c|c|c|c|c|c|c|c|c|c|c|c|c|c|}
\hline \multicolumn{4}{|c|}{ Anions meq/l } & \multicolumn{4}{|c|}{ Cations meq/l } & \multirow{2}{*}{$\begin{array}{c}\mathrm{EC} \\
\mathrm{dS} / \mathrm{m}\end{array}$} & \multirow{2}{*}{$\mathrm{pH}$} & \multirow{2}{*}{ Texture } & \multirow{2}{*}{$\begin{array}{c}\text { Clay } \\
\%\end{array}$} & \multirow{2}{*}{$\begin{array}{c}\text { Silt } \\
\%\end{array}$} & \multirow{2}{*}{$\begin{array}{c}\text { Sand } \\
\%\end{array}$} \\
\hline $\mathrm{SO}_{4}=$ & $\mathrm{Cl}^{-}$ & $\mathrm{HCO}_{3}{ }^{-}$ & $\mathrm{Co}_{3}=$ & $\mathrm{Na}^{+}$ & $\mathrm{K}^{+}$ & $\mathrm{Mg}^{++}$ & $\mathrm{Ca}^{++}$ & & & & & & \\
\hline 15.10 & 25.00 & 2.02 & - & 22.35 & 1.82 & 6.80 & 11.20 & 3.45 & 7.59 & Sandy & 13.8 & 30.56 & 55.60 \\
\hline
\end{tabular}


The soil of plastic house ( $6 \mathrm{~m}$ width, $40 \mathrm{~m}$ length and $2.5 \mathrm{~m}$ height) was ploughed and divided into three ridges ( $1 \mathrm{~m}$ width $\times 40 \mathrm{~m}$ length). Each ridge was divided into two equal divisions ( 1 m width $\times 20$ m length) as main plots for both hybrids of pepper. Each ridge of main plots was divided into five equal divisions ( $1 \mathrm{~m}$ width $\times 4 \mathrm{~m}$ length) as sub main plots for organic fertilizer treatments. Five organic fertilizers of quail, turkey chicken, rabbit manures and compost as recommended dose of nitrogen for sweet pepper (300 $\mathrm{kg} / \mathrm{feddan}$ ) in sandy soil under greenhouse conditions (El-Sayed, 2006)were investigated for organic production of two hybrids of sweet pepper.All different manures were obtained fromFaculty of Agriculture Farm, Cairo University, these manures were composted aerially for three weeks. Commercial compost was used.The chemical analyses of different organic fertilizers are illustrated in Table 2.

Table 2.Chemical analyses of the different organic fertilizers

\begin{tabular}{|l|c|c|c|c|c|c|c|c|c|c|}
\hline \multirow{2}{*}{ Type } & \multirow{2}{*}{ Hum \% } & pH & OM & \multicolumn{3}{|c|}{$\begin{array}{c}\text { Macro elements } \\
\text { (:10) }\end{array}$} & \multicolumn{4}{c|}{$\begin{array}{c}\text { Micro elements } \\
\text { (ppm) }\end{array}$} \\
\cline { 5 - 11 } & & & & $\mathbf{N}$ & $\mathbf{P}$ & $\mathbf{K}$ & $\mathbf{F e}$ & $\mathbf{Z n}$ & $\mathbf{M n}$ & $\mathbf{C u}$ \\
\hline Quail & 2.0 & 6.5 & 57.7 & 3.6 & 1.0 & 1.4 & 1130 & 871 & 337 & 33 \\
\hline Turkey & 2.0 & 7.7 & 57.4 & 3.9 & 1.8 & 1.3 & 1712 & 535 & 293 & 64 \\
Chicken & 2.0 & 8.1 & 63.2 & 3.3 & 1.8 & 1.6 & 1030 & 189 & 183 & 19 \\
\hline Rabbit & 2.6 & 7.6 & 32.2 & 2.8 & 0.8 & 1.2 & 3335 & 195 & 185 & 33 \\
\hline Compost & 25.0 & 7.5 & 32.4 & 1.2 & 0.7 & 1.4 & 2650 & 96 & 238 & 46 \\
\hline
\end{tabular}

All quantities of different organic fertilizers $(2.024,1.868,2.208,2.617$ and $7.440 \mathrm{~kg} / \mathrm{m}^{2}$ from quail, turkey chicken, rabbit manures and compost respectively) as recommended dose of nitrogen were incorporated into ridges at once before one week of transplanting.

Split-plot design with three replicates was used in plastic house trails, where the two hybrids were adapted in the main plots and the organic fertilizer treatments were randomized in the sub main plots. The plot area was $4 \mathrm{~m}^{2}$ on form ridge included 16 plants in 2 rows;the space within plants and between rows was $50 \mathrm{~cm}$, while the space between ridges was $75 \mathrm{~cm}$. The plants were irrigated by drip irrigation $(4 \mathrm{~L} / \mathrm{hr})$ daily according to water rations program fortomato plantsunder plastichousesat Giza Governorate (Ministry of Agriculture and Land Reclamation, 1988).

After 90 days from transplanting, three plants per replicate were randomly chosen to measure plant height and number of leaves/plant. Chlorophyll reading in the fourth upper leaf was measured by using Minolta Chlorophyll Meter Spad 501. The percentage of nitrogen, phosphorous and potassium were determined in the dry matter of fourth upper leaf according to Cottenie et al. (1982).

Nitrogen percent was determined by Kjeldahl method according to the procedure described by FAO (1980). Phosphorus percent was determined using spectrophotometer according to Watanabe and Olsen (1965). Potassium percent was determined spectrometrically using Phillips Unicum Atomic Absorption Spectrometer as described by Chapman and Pratt (1961). Harvesting of mature pepper fruits was at full color stage, which began on 1 and 15 January and finished on 15 and 30 May in the first and second 
seasons respectively. Early yield was recorded during the first two harvests.Total yield per meter square, number of fruits per plant were recorded after each harvesting accumulatively.Average of weight, diameter, firmness, TSS and vitamin C of mature fruits (fully color stage) were measured, as well.Fruit firmness was measured by Pressure Tester. TSS was measured by using Digital Refractometer. Vitamin $C$ in fruit was determined as described in FAO (1980).

Data of the two seasons were arranged and statistically analyzed by the analysis of variances according to Snedecor and Cochran (1980) with SAS software, version 2004. Comparison of treatment means was done using Tukey test at significance level 0.05 .

\section{RESULTS AND DISCUSSION}

\section{Vegetative growth}

Data on vegetative growth parameters, i.e. plant height, leaf number/plant and chlorophyll reading in leaves for the studied hybrids under different organic fertilizers were presented in Table 3 . Such data reveal that there were no significant differences between two hybrids of bell pepper in plant height and leaf number. Chlorophyll reading in leaves of Bunjii hybrid was higher than Shunghi hybrid.

Effect organic fertilizersgave significant differences on vegetative growth characteristics. However,compost treatment gave the highest value of plant height; chicken and turkey manure treatments came in the second order, then rabbit manure treatment; whereas the lowest plant height was recorded by quail manure. The maximum leaf number/plant was obtained by compost, chicken and turkey manures; rabbit manure treatment came in the second order, finally quail manure gave the lowest leaf number.The highest reading of chlorophyll in pepper leaves was observed in plants treated with compost, chicken and turkey manures. While the lowest reading of chlorophyll was obtained by quail and rabbit manure treatments. These results were true in the two seasons. A promotion effect of compost on vegetative growth and chlorophyll reading might be attributed to that compost has advantages more than other manures because it contain on essential nutrients on balance form (Masarirambiet al., 2010; Abou-El-Hassan and Desoky, 2013), decompose and stable organic matters; compost is usually applied at greater rate cause it contain low N\% (Table 2). All these advantagesled to compost came more effect than other manures on improving the soil fertility and ability of sandy soil to hold water and nutrients for plant absorb. Thus applying compost increased of plant growth and chlorophyll reading of bell pepper plants.Similar results were reported by Abdel-El-Moez et al. (2001), Arancon et al. (2005). Ewulo et al. (2007).

The interaction between organic fertilizers and hybrids had significant effect on vegetative growth characteristics and chlorophyll readingof bell pepper in the two seasons. However, the highest values of all vegetative growth parameters were recorded by compost and chicken manure with both hybrids. Meanwhile, the lowest values were obtained byquail and rabbit manure with two hybrids. 
Table 3. Effect of different organic fertilizers on vegetative growth characters of bell pepper plants during 2013/2014 and 2014/2015 seasons

\begin{tabular}{|c|c|c|c|c|c|c|c|}
\hline \multirow{2}{*}{\multicolumn{2}{|c|}{ Characters }} & \multicolumn{3}{|c|}{ First season } & \multicolumn{3}{|c|}{ Second season } \\
\hline & & $\begin{array}{c}\text { P. height } \\
\text { cm }\end{array}$ & $\begin{array}{c}\text { Leaf } \\
\text { NO/plant }\end{array}$ & $\begin{array}{c}\text { Chloro. } \\
\text { spad }\end{array}$ & $\begin{array}{c}\text { P. height } \\
\text { cm }\end{array}$ & $\begin{array}{c}\text { Leaf } \\
\text { NO/plant }\end{array}$ & $\begin{array}{c}\text { Chloro. } \\
\text { spad }\end{array}$ \\
\hline \multicolumn{2}{|c|}{ Treatments } & \multicolumn{6}{|c|}{ Effect of hybrids } \\
\hline \multicolumn{2}{|l|}{ Bunjii } & $4.87 \mathrm{a}$ & $60.60 \mathrm{a}$ & $58.60 \mathrm{a}$ & $58.97 \mathrm{a}$ & $63.80 \mathrm{a}$ & $61.40 \mathrm{a}$ \\
\hline \multicolumn{2}{|l|}{ Shunghi } & $.40 \mathrm{a}$ & $58.00 \mathrm{a}$ & $57.13 \mathrm{~b}$ & $57.50 \mathrm{a}$ & $20 \mathrm{a}$ & $9.93 \mathrm{~b}$ \\
\hline \multirow{2}{*}{\multicolumn{2}{|c|}{ Quail }} & \multicolumn{6}{|c|}{ Effect of organic fertilizers } \\
\hline & & $45.00 \mathrm{~d}$ & $51.17 \mathrm{c}$ & $55.00 \mathrm{~b}$ & $48.00 \mathrm{e}$ & $53.17 \mathrm{c}$ & $57.00 \mathrm{c}$ \\
\hline \multicolumn{2}{|l|}{ Turkey } & $56.17 \mathrm{~b}$ & $60.67 \mathrm{ab}$ & $58.50 \mathrm{a}$ & $59.57 \mathrm{c}$ & $64.67 \mathrm{a}$ & $60.50 \mathrm{~b}$ \\
\hline \multicolumn{2}{|l|}{ Chicken } & $57.83 \mathrm{~b}$ & $63.00 \mathrm{a}$ & $59.50 \mathrm{a}$ & $63.13 \mathrm{~b}$ & $67.00 \mathrm{a}$ & $63.50 \mathrm{a}$ \\
\hline \multicolumn{2}{|l|}{ Rabbit } & $.00 \mathrm{c}$ & $57.17 \mathrm{~b}$ & 56. & $\mathrm{~b}$ & $59.17 \mathrm{~b}$ & $8.50 \mathrm{c}$ \\
\hline \multirow{2}{*}{\multicolumn{2}{|c|}{ Compost }} & $67 \mathrm{a}$ & $64.50 \mathrm{a}$ & $59.83 \mathrm{a}$ & $66.67 \mathrm{a}$ & $68.50 \mathrm{a}$ & $63.83 \mathrm{a}$ \\
\hline & & \multicolumn{6}{|c|}{ Effect of the interaction } \\
\hline \multirow{5}{*}{ Bunjii } & Quail & $46.67 \mathrm{~cd}$ & $51.67 \mathrm{~d}$ & $55.67 \mathrm{~cd}$ & 49.67 ef & $53.67 \mathrm{e}$ & $57.67 \mathrm{de}$ \\
\hline & Turkey & $56.67 \mathrm{ab}$ & $62.00 \mathrm{ab}$ & $59.33 \mathrm{ab}$ & $59.67 \mathrm{bc}$ & $66.00 \mathrm{abc}$ & $61.33 \mathrm{bc}$ \\
\hline & Chicken & $58.67 \mathrm{a}$ & $64.67 \mathrm{ab}$ & $60.33 a b$ & $63.67 \mathrm{ab}$ & $68.67 \mathrm{ab}$ & $64.33 \mathrm{a}$ \\
\hline & Rabbit & $50.67 \mathrm{bc}$ & $58.67 \mathrm{bc}$ & $57.00 \mathrm{bc}$ & 54.67 cde & $60.67 \mathrm{~cd}$ & $59.00 \mathrm{~cd}$ \\
\hline & Compost & $61.67 \mathrm{a}$ & $66.00 \mathrm{a}$ & $60.67 \mathrm{a}$ & $66.67 \mathrm{a}$ & $70.00 \mathrm{a}$ & $64.67 \mathrm{a}$ \\
\hline \multirow{5}{*}{ Shunghi } & Quail & $43.33 \mathrm{~d}$ & $50.67 \mathrm{~d}$ & $54.33 \mathrm{~d}$ & $46.33 \mathrm{f}$ & $52.67 \mathrm{e}$ & $56.33 \mathrm{e}$ \\
\hline & Turkey & $55.67 \mathrm{ab}$ & $59.33 \mathrm{bc}$ & $57.67 \mathrm{bc}$ & $58.67 \mathrm{bcd}$ & $63.33 \mathrm{bcd}$ & $59.67 \mathrm{~cd}$ \\
\hline & Chicken & $57.00 \mathrm{a}$ & $61.33 \mathrm{abc}$ & $58.67 \mathrm{ab}$ & $62.00 \mathrm{ab}$ & $65.33 \mathrm{abc}$ & $62.67 \mathrm{ab}$ \\
\hline & Rabbit & $49.33 \mathrm{~cd}$ & $55.67 \mathrm{~cd}$ & $56.00 \mathrm{~cd}$ & 53.33de & $57.67 \mathrm{de}$ & $58.00 \mathrm{de}$ \\
\hline & Compost & $61.67 \mathrm{a}$ & $63.00 \mathrm{ab}$ & $59.00 \mathrm{ab}$ & $66.67 \mathrm{a}$ & $67.00 \mathrm{ab}$ & $63.00 \mathrm{ab}$ \\
\hline
\end{tabular}

Means in same column by similar letters are not statistically different at 0.05 level according to Tukey test.

\section{Nutritional status}

Data recorded in Table 4 show clearly that percentage of NPK in the Bunjii hybrid was significantly higher than Shunghi hybrid in the both seasons except $\mathrm{K}$ percent there was no significant different between both hybrids in the second season. These results might be correlated with the gene action of the tested hybrids. These results are agreed with those obtained by Geleta et al. (2005) and Deepaa et al. (2006) on sweet pepper.

Organic fertilizers showed significant effecton nutritional status of bell pepper plants. However,the highest percent of $\mathrm{N}$ in plants was preceded by compost treatment. The treatments of chicken and turkey manure came in the second order, then rabbit manure treatment. The lowest percent of $\mathrm{N}$ was obtained by quail manure. The highest percent of $P$ in bell pepper plants were resulted by compost, chicken and turkey manures; while quail and rabbit manures gave the lowest percent of $P$. Using compost, chicken and turkey manures produced the highest percent of $\mathrm{K}$ in bell pepper plants, quail manure treatment came in the second order, finally rabbit manure gave the lowest percent of K. The superiority of NPK content in bell pepper plants by compost treatment may be due to thatcompost is usually applied at much greater rates; therefore, it can have a significant cumulative effect on nutrient availability. The great rate of compost also increasesactivity of beneficial microorganisms in soil, which help in promotion of nutrient availability by 
atmospheric nitrogen fixation, phosphate dissolving and potassium releasing (Miyasaka et al., 1997; Ahmad et al., 2008; Fiorentino and Fagnano, 2011). All these led to increment NPK content of bell pepper plants. On the other hand, increase $\mathrm{P}$ and $\mathrm{K}$ content of chicken manure treatmentmay be due to increase percentage these nutrients in chicken manure (Table 2). Harmony results were observed by Alabi (2006) and Dawaet al. (2012), they reported thatN, $\mathrm{P}$ and $\mathrm{K} \%$ increased in sweet pepper leaves when plants were fertilized by chicken manure.

The interaction between organic fertilizers and hybrids had significant effect on NPK percent of bell pepper plants during in the two seasons. However, the highest N\% was recorded by using compost with both hybrids. Meanwhile, the lowest $\mathrm{N} \%$ was obtained by quail manure with two hybrids. The highest $\mathrm{P}$ and $\mathrm{K} \%$ was recorded by using compost, chicken and turkey manure with both hybrids. On the contrary, the lowest $\mathrm{P}$ and $\mathrm{K} \%$ was obtained by quail manure and rabbit manure respectively with both hybrids.

Table 4. Effect of different organic fertilizers on NPK percent of bell pepper plants during 2013/2014 and 2014/2015 seasons

\begin{tabular}{|l|c|c|c|c|c|c|}
\hline \multirow{2}{*}{ Characters } & \multicolumn{7}{|c|}{ First season } & \multicolumn{3}{c|}{ Second season } \\
\cline { 2 - 8 } & $\begin{array}{c}\mathbf{N} \\
\%\end{array}$ & $\begin{array}{c}\mathbf{P} \\
\%\end{array}$ & $\begin{array}{c}\mathbf{K} \\
\%\end{array}$ & $\begin{array}{c}\mathbf{N} \\
\%\end{array}$ & $\begin{array}{c}\mathbf{P} \\
\%\end{array}$ & $\begin{array}{c}\mathbf{K} \\
\%\end{array}$ \\
\hline Treatments & \multicolumn{7}{|c|}{ Effect of hybrids } \\
\hline Bunjii & $4.27 \mathrm{a}$ & $0.377 \mathrm{a}$ & $4.27 \mathrm{a}$ & $4.267 \mathrm{a}$ & $0.390 \mathrm{a}$ & $4.29 \mathrm{a}$ \\
\hline Shunghi & $4.20 \mathrm{~b}$ & $0.350 \mathrm{~b}$ & $4.20 \mathrm{~b}$ & $4.202 \mathrm{~b}$ & $0.367 \mathrm{~b}$ & $4.28 \mathrm{a}$ \\
\hline \multirow{2}{*}{ Quail } & $3.62 \mathrm{~d}$ & $0.303 \mathrm{c}$ & $4.14 \mathrm{~b}$ & $3.62 \mathrm{~d}$ & $0.330 \mathrm{c}$ & $4.18 \mathrm{~b}$ \\
\hline Turkey & $4.45 \mathrm{~b}$ & $0.363 \mathrm{abc}$ & $4.39 \mathrm{a}$ & $4.45 \mathrm{~b}$ & $0.373 \mathrm{~b}$ & $4.42 \mathrm{a}$ \\
\hline Chicken & $4.49 \mathrm{~b}$ & $0.390 \mathrm{abc}$ & $4.43 \mathrm{a}$ & $4.49 \mathrm{~b}$ & $0.417 \mathrm{a}$ & $4.47 \mathrm{a}$ \\
\hline Rabbit & $3.79 \mathrm{c}$ & $0.337 \mathrm{bc}$ & $3.70 \mathrm{c}$ & $3.79 \mathrm{c}$ & $0.357 \mathrm{bc}$ & $3.82 \mathrm{c}$ \\
\hline Compost & $4.83 \mathrm{a}$ & $0.423 \mathrm{abc}$ & $4.53 \mathrm{a}$ & $4.83 \mathrm{a}$ & $0.433 \mathrm{a}$ & $4.57 \mathrm{a}$ \\
\hline \multirow{5}{*}{ Bunjii } & \multicolumn{7}{|c|}{ Effect of the interaction } \\
\hline
\end{tabular}
Means in same column by similar letters are not statistically different at 0.05 leve according to Tukey test.

\section{Yield component}

It is evident from the data in Table 5 that there were significant differences among the various investigated entries with regard to yield component of bell pepper. In both seasons, Bunjii hybrid gave the highest values of early, total yield, number and weight of bell pepper fruits compared with Shunghi hybrid. This result was in harmony with previous findings of Geleta et al. (2005) and Deepaa et al. (2006) they reported that the observed differences in yield 
component of sweet pepper cultivars are mainly due to the genotype of each cultivar.

Organic fertilizers had significant effect on yield component. However,the highest values of early and total yield of bell pepper plants were produced by compost treatment; chicken manure treatment came in the second order, turkey manure treatment came in the third order, then rabbit manure treatment, finally the lowest values of early and total yield were recorded by quail manure.Using compost and chicken manures produced the highest number and weight of fruit, turkey manure treatment came in thesecond order, then rabbit manure treatment, finally quail manure produced the lowest number and weight of fruit.The positive effect of these treatments on yield component may be due to increase uptake of $\mathrm{N}, \mathrm{P}$ and $\mathrm{K}$ by these plants as shown in Table 4 which resulted in increased plant growth characteristics as shown in Table 3. The improving of plant growth led to better carbohydrate build up which increased the early, total yield number and weight fruit of bell pepper. In this concern, Suge et al. (2011) reported similar results and explained that addition of suitable organic matter in the soil improves the soil physical and chemical properties which encourages better root development, increased nutrient uptake and water holding capacity which led to higher yield component of eggplant. Obtained results agreed with those obtained by Salama and Zake (2000), Shehata et al. (2004), Awodun et al. (2007), HuezLopez et al. (2011) and Zayed et al. (2013).

Table 5. Effect of different organic fertilizers on yield component of bell pepper plants during 2013/2014and 2014/2015 seasons

\begin{tabular}{|c|c|c|c|c|c|c|c|c|c|}
\hline \multirow{2}{*}{\multicolumn{2}{|c|}{ na }} & \multicolumn{4}{|c|}{ First season } & \multicolumn{4}{|c|}{ Second season } \\
\hline & & $\begin{array}{c}\mathrm{E} . \\
\text { yield } \\
\mathrm{Kg} / \mathrm{m}^{2}\end{array}$ & $\begin{array}{c}\mathrm{T} . \\
\text { yield } \\
\mathrm{Kg} / \mathrm{m}^{2}\end{array}$ & $\begin{array}{c}\text { Fruit } \\
\text { NO } \\
\text { /plant }\end{array}$ & \begin{tabular}{|c|}
$F$. \\
weight \\
g
\end{tabular} & \begin{tabular}{|c}
$\mathrm{E}$. \\
yield \\
$\mathrm{Kg} / \mathrm{m}^{2}$
\end{tabular} & $\begin{array}{c}\mathrm{T} . \\
\text { yield } \\
\mathrm{Kg} / \mathrm{m}^{2}\end{array}$ & \begin{tabular}{|c|} 
Fruit \\
NO \\
/plant
\end{tabular} & $\begin{array}{c}\text { F. } \\
\text { weight } \\
\text { g }\end{array}$ \\
\hline \multicolumn{2}{|c|}{ Treatments } & \multicolumn{8}{|c|}{ Effect of hybrids } \\
\hline Bunjii & & $2.44 \mathrm{a}$ & $7.88 \mathrm{a}$ & $18.87 \mathrm{a}$ & $145 \mathrm{a}$ & $2.69 \mathrm{a}$ & $8.22 \mathrm{a}$ & $22.13 \mathrm{a}$ & $148 \mathrm{a}$ \\
\hline \multicolumn{2}{|l|}{ Shunghi } & $1.89 \mathrm{~b}$ & $6.97 \mathrm{~b}$ & $17.78 \mathrm{~b}$ & $140 \mathrm{~b}$ & $2.14 \mathrm{~b}$ & $7.31 \mathrm{~b}$ & $20.58 \mathrm{~b}$ & $141 b$ \\
\hline & & \multicolumn{8}{|c|}{ Effect of organic fertilizers } \\
\hline \multicolumn{2}{|l|}{ Quail } & $1.24 \mathrm{e}$ & $5.40 \mathrm{e}$ & $15.07 \mathrm{c}$ & $127 d$ & $1.46 \mathrm{e}$ & $5.75 \mathrm{e}$ & $18.07 \mathrm{~d}$ & $128 d$ \\
\hline \multicolumn{2}{|l|}{ Turkey } & $2.18 \mathrm{c}$ & $7.88 \mathrm{c}$ & $19.80 \mathrm{a}$ & $143 \mathrm{~b}$ & $2.44 \mathrm{c}$ & $8.21 \mathrm{c}$ & $30 \mathrm{~b}$ & $143 \mathrm{~b}$ \\
\hline \multicolumn{2}{|l|}{ Chicken } & $2.49 \mathrm{~b}$ & $8.17 \mathrm{~b}$ & $3 \mathrm{a}$ & $151 \mathrm{a}$ & $2.76 \mathrm{~b}$ & $8.52 \mathrm{~b}$ & $3 \mathrm{~b}$ & $156 \mathrm{a}$ \\
\hline \multicolumn{2}{|l|}{ Rabbit } & $1.81 \mathrm{~d}$ & $6.92 \mathrm{~d}$ & $16.83 \mathrm{~b}$ & $134 \mathrm{c}$ & $2.03 d$ & $7.27 \mathrm{~d}$ & $18.97 \mathrm{c}$ & $137 \mathrm{c}$ \\
\hline \multirow{2}{*}{\multicolumn{2}{|c|}{ Compost }} & $3.11 \mathrm{a}$ & $8.73 \mathrm{a}$ & $20.13 \mathrm{a}$ & $157 \mathrm{a}$ & $3.38 \mathrm{a}$ & $9.08 \mathrm{a}$ & $24.13 \mathrm{a}$ & $158 \mathrm{a}$ \\
\hline & & \multicolumn{8}{|c|}{ Effect of the interaction } \\
\hline \multirow{5}{*}{ Bunjii } & Quan & $1.42 \mathrm{e}$ & $5.82 \mathrm{f}$ & $15.50 \mathrm{~d}$ & $128 \mathrm{e}$ & $1.64 \mathrm{e}$ & $6.17 \mathrm{f}$ & \begin{tabular}{|l|}
$18.50 \mathrm{e}$ \\
\end{tabular} & $128 \mathrm{~d}$ \\
\hline & Turkey & $2.42 \mathrm{c}$ & $8.57 \mathrm{~b}$ & $20.66 \mathrm{a}$ & $145 \mathrm{bc}$ & $2.68 \mathrm{c}$ & $8.90 \mathrm{~b}$ & $23.66 \mathrm{ab}$ & $147 \mathrm{~b}$ \\
\hline & Chicken & $2.79 \mathrm{~b}$ & $8.74 \mathrm{ab}$ & $20.43 a b$ & $155 a b$ & $3.05 \mathrm{~b}$ & $9.09 \mathrm{ab}$ & $23.43 \mathrm{~b}$ & $162 \mathrm{a}$ \\
\hline & Rabbit & $2.07 \mathrm{~d}$ & $7.13 \mathrm{~d}$ & $17.04 \mathrm{~d}$ & $137 \mathrm{cde}$ & $2.29 \mathrm{~d}$ & $7.48 \mathrm{~d}$ & $20.33 \mathrm{~d}$ & $139 c$ \\
\hline & Compost & $3.51 \mathrm{a}$ & $9.12 \mathrm{ab}$ & $20.74 \mathrm{a}$ & $159 \mathrm{a}$ & $3.78 \mathrm{a}$ & $9.46 \mathrm{a}$ & $24.74 \mathrm{a}$ & $164 \mathrm{a}$ \\
\hline \multirow{5}{*}{ Shunghi } & Quail & $1.06 \mathrm{f}$ & $4.98 \mathrm{~g}$ & $14.58 \mathrm{e}$ & $125 \mathrm{e}$ & $1.28 \mathrm{f}$ & $5.33 \mathrm{~g}$ & $17.58 \mathrm{e}$ & $123 d$ \\
\hline & Turkey & $1.93 \mathrm{~d}$ & $7.19 \mathrm{~d}$ & $18.95 \mathrm{c}$ & $141 \mathrm{~cd}$ & $2.20 \mathrm{~d}$ & $7.52 \mathrm{~d}$ & $21.95 \mathrm{c}$ & $139 c$ \\
\hline & Chicken & $2.20 \mathrm{~cd}$ & $7.60 \mathrm{c}$ & $19.27 \mathrm{c}$ & $147 \mathrm{bc}$ & $2.46 \mathrm{~cd}$ & $7.95 \mathrm{c}$ & $22.27 \mathrm{c}$ & $150 \mathrm{~b}$ \\
\hline & Rabbit & $1.54 \mathrm{e}$ & $6.72 \mathrm{e}$ & $16.62 \mathrm{~d}$ & $132 \mathrm{de}$ & $1.76 \mathrm{e}$ & $7.07 \mathrm{e}$ & \begin{tabular}{|l|}
$17.62 \mathrm{e}$ \\
\end{tabular} & $136 \mathrm{c}$ \\
\hline & Compost & $2.71 \mathrm{~b}$ & $8.34 \mathrm{~b}$ & $19.50 \mathrm{bc}$ & $154 \mathrm{ab}$ & $2.97 \mathrm{~b}$ & $8.69 \mathrm{~b}$ & $23.50 \mathrm{~b}$ & $152 b$ \\
\hline
\end{tabular}

Means in same column by similar letters are not statistically different at 0.05 level according to Tukey test. 
The interaction between organic fertilizers and hybrids had significant effect on early, total yield $/ \mathrm{m}^{2}$ and fruit number/plant of bell pepper during in the two seasons. However, the highest value of early yield was recorded by using compost with Bunjii hybrid. On the contrary, the lowest value was obtained by quail manure with Shunghi hybrid. The highest values of total yield and fruit number were produced by using compost and chicken manure with Bunjii hybrid. Conversely, the lowest values were obtained by quail manure with Shunghi hybrid. Meanwhile, the interaction between organic fertilizers and hybrids had no significant effect on fruit weight of bell pepper.

\section{Fruit quality}

\section{Physical properties of fruit}

Data on fruit quality, i.e. fruit diameter, fruit length and fruit firmness for the studied cultivars under different nitrogen levels were presented in Table 6. Such data reveal that there were significant differences in most studied fruit quality among red fruit hybrid and yellow fruit hybrid. In this respect, Bunjii hybrid gave fruits of pepper more diameter and length than fruits of Shunghi hybrid. These results might be correlated with the gene action of the studied hybrids. These results are agreed with those obtained by Geleta et al.(2005) and Deepaa et al.(2006) on sweet pepper.

Table 6. Effect of different organic fertilizers on fruit quality of bell pepper during 2013/2014 and 2014/2015 seasons

\begin{tabular}{|c|c|c|c|c|c|c|c|}
\hline \multirow{2}{*}{\multicolumn{2}{|c|}{ Characters }} & \multicolumn{3}{|c|}{ First season } & \multicolumn{3}{|c|}{ Second season } \\
\hline & & $\begin{array}{c}\text { Fruit } \\
\text { diameter } \\
\mathbf{c m} \\
\end{array}$ & $\begin{array}{c}\text { Fruit } \\
\text { length } \\
\text { cm }\end{array}$ & $\begin{array}{c}\text { Fruit } \\
\text { firmness } \\
\mathrm{Kg} / \mathrm{cm}^{2}\end{array}$ & \begin{tabular}{|c|} 
Fruit \\
diameter \\
cm \\
\end{tabular} & $\begin{array}{c}\text { Fruit } \\
\text { length } \\
\text { cm } \\
\end{array}$ & \begin{tabular}{|c|} 
Fruit \\
firmness \\
$\mathrm{Kg} / \mathrm{cm}^{2}$ \\
\end{tabular} \\
\hline \multicolumn{2}{|c|}{ Treatments } & \multicolumn{6}{|c|}{ Effect of hybrids } \\
\hline \multicolumn{2}{|l|}{ Buniii } & $8.41 \mathrm{a}$ & $9.07 \mathrm{a}$ & $3.05 \mathrm{a}$ & $8.68 \mathrm{a}$ & $9.54 \mathrm{a}$ & $3.13 \mathrm{a}$ \\
\hline \multicolumn{2}{|l|}{ Shunghi } & $8.27 \mathrm{~b}$ & $8.89 \mathrm{~b}$ & $2.88 \mathrm{a}$ & $8.54 \mathrm{~b}$ & $9.37 \mathrm{~b}$ & $2.97 \mathrm{a}$ \\
\hline & & \multicolumn{6}{|c|}{ Effect of organic fertilizers } \\
\hline \multicolumn{2}{|l|}{ Quail } & $7.87 \mathrm{~b}$ & $8.47 \mathrm{c}$ & $2.98 \mathrm{a}$ & $8.07 \mathrm{~b}$ & $8.95 \mathrm{c}$ & $3.05 \mathrm{a}$ \\
\hline \multicolumn{2}{|l|}{ Turkey } & $8.53 \mathrm{a}$ & $9.10 \mathrm{~b}$ & $2.90 \mathrm{a}$ & $8.83 \mathrm{a}$ & $9.56 \mathrm{~b}$ & $3.00 \mathrm{a}$ \\
\hline \multicolumn{2}{|l|}{ Chicken } & $8.63 \mathrm{a}$ & $9.22 \mathrm{~b}$ & $2.98 \mathrm{a}$ & $8.93 \mathrm{a}$ & $9.68 \mathrm{ab}$ & $3.10 \mathrm{a}$ \\
\hline \multicolumn{2}{|l|}{ Rabbit } & $8.03 \mathrm{~b}$ & $8.63 \mathrm{c}$ & $2.88 \mathrm{a}$ & $8.23 \mathrm{~b}$ & $9.14 \mathrm{c}$ & $2.95 \mathrm{a}$ \\
\hline \multirow{2}{*}{\multicolumn{2}{|c|}{ Compost }} & $8.70 \mathrm{a}$ & $9.48 \mathrm{a}$ & $3.07 \mathrm{a}$ & $9.00 \mathrm{a}$ & $9.94 \mathrm{a}$ & $3.13 \mathrm{a}$ \\
\hline & & \multicolumn{6}{|c|}{ Effect of the interaction } \\
\hline \multirow{5}{*}{ Bunjii } & Quail & $7.90 \mathrm{c}$ & $8.53 \mathrm{~d}$ & $3.10 \mathrm{a}$ & $8.10 \mathrm{~b}$ & $9.04 \mathrm{de}$ & $3.17 \mathrm{a}$ \\
\hline & Turkey & $8.63 \mathrm{a}$ & $9.17 \mathrm{~b}$ & $2.93 \mathrm{a}$ & $8.95 \mathrm{a}$ & $9.63 \mathrm{~b}$ & $3.07 \mathrm{a}$ \\
\hline & Chicken & $8.70 \mathrm{a}$ & $9.30 \mathrm{ab}$ & $3.07 \mathrm{a}$ & $9.02 \mathrm{a}$ & $9.76 \mathrm{ab}$ & $3.20 \mathrm{a}$ \\
\hline & Rabbit & $8.07 \mathrm{bc}$ & $8.70 \mathrm{~cd}$ & $2.93 \mathrm{a}$ & $8.27 \mathrm{~b}$ & 9.16 cde & $3.00 \mathrm{a}$ \\
\hline & Compost & $8.77 \mathrm{a}$ & $9.67 \mathrm{a}$ & $3.20 \mathrm{a}$ & $9.09 \mathrm{a}$ & $10.13 \mathrm{a}$ & $3.20 \mathrm{a}$ \\
\hline \multirow{5}{*}{ Shunghi } & Quail & $7.83 \mathrm{c}$ & $8.40 \mathrm{~d}$ & $2.87 \mathrm{a}$ & $8.03 \mathrm{~b}$ & $8.86 \mathrm{e}$ & $2.93 \mathrm{a}$ \\
\hline & Turkey & $8.43 \mathrm{ab}$ & $9.03 \mathrm{bc}$ & $2.87 \mathrm{a}$ & $8.75 \mathrm{a}$ & $9.49 \mathrm{bcd}$ & $2.93 \mathrm{a}$ \\
\hline & Chicken & $8.53 \mathrm{a}$ & $9.13 \mathrm{bc}$ & $2.90 \mathrm{a}$ & $8.85 \mathrm{a}$ & $9.59 \mathrm{bc}$ & $3.00 \mathrm{a}$ \\
\hline & Rabbit & $7.97 \mathrm{c}$ & $8.57 \mathrm{~d}$ & $2.83 \mathrm{a}$ & $8.17 \mathrm{~b}$ & $9.12 \mathrm{de}$ & $2.90 \mathrm{a}$ \\
\hline & Compost & $8.60 \mathrm{a}$ & $9.30 \mathrm{ab}$ & $2.93 \mathrm{a}$ & $8.92 \mathrm{a}$ & $9.76 \mathrm{ab}$ & $3.07 \mathrm{a}$ \\
\hline
\end{tabular}

Means in same column by similar letters are not statistically different at 0.05 level according to Tukey test. 
Organic fertilizers showed significant effect on diameter and length of bell pepper fruits in the two seasons. Applying compost, chicken and turkey manures increased the fruit diameter of bell pepper compared with using rabbit and quail manures. Using compost produced the highest fruit length; chicken and turkey manure treatments came in thesecond order, finally rabbit and quail manures gave the lowest values of fruit length. There were no significant differences among all organic fertilizer treatments concerning fruit firmness of bell pepper. The superiority of these treatments on diameter and length of bell pepper fruits might be due to increase vegetative growth of these plants as shown in Table 3, which led to better carbohydrate build up, thus increased diameter and length of bell pepper fruits. These results are in harmony with those obtained by Amorand Del (2007), Arafa and Shalabey (2007), Szafirowska and Elkner (2008) working on pepper and Suge et al. (2011) working on eggplant.

The interaction between organic fertilizers and hybrids had significant effect on diameter and length of bell pepper fruits in the two seasons. However, the highest fruit diameter was recorded by using compost, chicken and turkey manures with both hybrids compared to rabbit and quail manures with both hybrids. Meanwhile, the interaction between organic fertilizers and hybrids had no significant effect on fruit firmness of bell pepper in both seasons.

\section{Chemical properties of fruit}

Data in Table 7 showed that there were no significant differences between two hybrids in percentage of TSS in bell pepper fruits. Vitamin C content of pepper fruits was higher in Shunghi hybrid than Bunjiihybrid. The superiority of Shunghi hybrid on vitamin $\mathrm{C}$ content of fruit might be due to the genotype of this hybrid.

Organic fertilizers had significant effect on TSS and vitamin C content of bell pepper fruits in the two seasons. Using compost and chicken manure gave the highest values of TSS andvitamin C in fruits compared to other organic fertilizers. These results were true in the both seasons. These results are in harmony with those obtained by Amorand Del (2007), Arafa and Shalabey (2007), Szafirowska and Elkner (2008) and Fawzy et al. (2012). 
Table 7. Effect of different organic fertilizers on TSS and vitamin C content of bell pepper fruits during 2013/2014 and 2014/2015 seasons

\begin{tabular}{|c|c|c|c|c|c|}
\hline \multirow{2}{*}{\multicolumn{2}{|c|}{ Characters }} & \multicolumn{2}{|c|}{ First season } & \multicolumn{2}{|c|}{ Second season } \\
\hline & & $\begin{array}{c}\text { TSS } \\
\%\end{array}$ & $\begin{array}{l}\text { Vitamin C } \\
\mathrm{g} / 100 \mathrm{~g}\end{array}$ & $\begin{array}{c}\text { TSS } \\
\%\end{array}$ & $\begin{array}{c}\text { Vitamin C } \\
\mathrm{g} / 100 \mathrm{~g}\end{array}$ \\
\hline \multicolumn{2}{|c|}{ Treatments } & \multicolumn{4}{|c|}{ Effect of hybrids } \\
\hline Bunjii & & $7.63 \mathrm{a}$ & $0.180 \mathrm{~b}$ & $7.66 \mathrm{a}$ & $0.184 \mathrm{~b}$ \\
\hline \multicolumn{2}{|l|}{ Shunghi } & $7.55 \mathrm{a}$ & $0.190 \mathrm{a}$ & $7.63 \mathrm{a}$ & $0.190 \mathrm{a}$ \\
\hline & & \multicolumn{4}{|c|}{ Effect of organic fertilizers } \\
\hline \multicolumn{2}{|l|}{ Quail } & $7.43 \mathrm{~b}$ & $0.180 \mathrm{~b}$ & $7.47 \mathrm{~b}$ & $0.183 \mathrm{~b}$ \\
\hline \multicolumn{2}{|l|}{ Turkey } & $7.50 \mathrm{~b}$ & $0.183 \mathrm{~b}$ & $7.50 \mathrm{~b}$ & $0.186 b$ \\
\hline \multicolumn{2}{|l|}{ Chicken } & $7.83 \mathrm{a}$ & $0.193 \mathrm{a}$ & $7.87 \mathrm{a}$ & $0.192 \mathrm{a}$ \\
\hline \multicolumn{2}{|l|}{ Rabbit } & $7.40 \mathrm{~b}$ & $0.183 \mathrm{~b}$ & $7.53 \mathrm{~b}$ & $0.184 b$ \\
\hline \multirow{2}{*}{\multicolumn{2}{|c|}{ Compost }} & $7.83 \mathrm{a}$ & $0.193 \mathrm{a}$ & $7.93 \mathrm{a}$ & $0.193 \mathrm{a}$ \\
\hline & & \multicolumn{4}{|c|}{ Effect of the interaction } \\
\hline \multirow{5}{*}{ Bunjii } & Quail & $7.47 \mathrm{bc}$ & $0.177 \mathrm{c}$ & $7.47 c$ & $0.179 \mathrm{e}$ \\
\hline & Turkey & $7.50 \mathrm{bc}$ & $0.180 \mathrm{bc}$ & $7.53 \mathrm{bc}$ & $0.181 \mathrm{de}$ \\
\hline & Chicken & $7.83 \mathrm{a}$ & $0.188 \mathrm{abc}$ & $7.83 a b c$ & $0.188 \mathrm{abc}$ \\
\hline & Rabbit & $7.43 \mathrm{c}$ & $0.181 \mathrm{bc}$ & $7.53 \mathrm{bc}$ & 0.183 cde \\
\hline & Compost & $7.90 \mathrm{a}$ & $0.190 \mathrm{ab}$ & $7.93 \mathrm{a}$ & $0.190 \mathrm{ab}$ \\
\hline \multirow{5}{*}{ Shunghi } & Quail & $7.37 \mathrm{a}$ & $0.183 \mathrm{bc}$ & $7.47 \mathrm{c}$ & $0.186 \mathrm{bcd}$ \\
\hline & Turkey & $7.50 \mathrm{bc}$ & $0.187 \mathrm{abc}$ & $7.47 c$ & $0.190 \mathrm{ab}$ \\
\hline & Chicken & $7.77 \mathrm{ab}$ & $0.198 \mathrm{a}$ & $7.83 \mathrm{abc}$ & $0.195 \mathrm{a}$ \\
\hline & Rabbit & $7.33 \mathrm{c}$ & $0.183 \mathrm{bc}$ & $7.47 \mathrm{c}$ & $0.183 \mathrm{cde}$ \\
\hline & Compost & $7.77 \mathrm{ab}$ & $0.198 \mathrm{a}$ & $7.90 \mathrm{ab}$ & $0.196 \mathrm{a}$ \\
\hline
\end{tabular}

Means in same column by similar letters are not statistically different at 0.05 leve according to Tukey test.

The interaction between organic fertilizers and hybrids had significant effect on TSS and vitamin C content of bell pepper fruits in both seasons.As compost and chicken manure treatments gave the highest values of TSS and vitamin $C$ in bell pepper fruits in both hybrids. On the other hand, quail manure and rabbit manure treatments produced the lowest values with two hybrids in both seasons.

\section{CONCLUSION}

In conclusion, this work showed that satisfactory bell pepper yield and qualitycould be obtained in organic production systems under plastic house conditions using compost or chicken manure as a recommended rate of nitrogen to reduce environment pollution caused by application of mineral fertilizers and sustain soil fertility.

\section{Acknowledgement}

This work has been supported by Science Technology Development Fund (STDF), Egypt under Project number 2076, . 


\section{REFERENCES}

Abdel-El-Moez, M.R., N. Gad and S.A. Wanas, 2001. Impact of banana compost added with or without elemental sulphur on nutrients uptake, yield, soil moisture depletion and water use efficiency of pepper plants. Annals of Agricultural Science, Moshtohor, 39(2): 1355-1372.

Abou-El-Hassan, S. and A.H. Desoky, 2013. Effect of compost and compost tea on organic production of head lettuce. J. Appl. Sci. Res., 9(11): 5650-5655.

Ahmad, R., S.M. Shehzad, A. Khalid, M. Arshad and M.H. Mahmood, 2008. Growth and yield response of wheat and maize to nitrogen and $\mathrm{L}$ tryptophan enriched compost. Pak. J. Bot., 39(2): 541-549.

Aksoy, U., 2001. Ecological Farming. II. Ecological Farming Symposium in Turkey. 14-16 December. Antalya.

Alabi, D.A., 2006. Effects of fertilizer phosphorus and poultry droppings treatments on growth and nutrient components of pepper Afric. J. Biotech., 5(8): 671-677.

Amor, F. and M. Del, 2007. Yield and fruit quality response of sweet pepper to organic and mineral fertilization. Renewable Agriculture and Food Systems, 22(3): 233-238.

Anant-Bahadur, Jagdish-Singh, K.P., Singh, A.K Upadhyan and Mathura-Rai, 2006. Effect of organic amendments and biofertilizers on growth, yield and quality attributes of Chinese cabbage. Indian J. of Agric. Sci., 76(10): 596- 598.

Arafa, M.M. and O.E. Shalabey, 2007. Effect of zinc and organic manures on yield and fruit chemical composition of pepper plants grown on newly reclaimed soils. Annals of Agricultural Science (Cairo). 52(2): 441-450.

Arancon, N.Q., C.A. Edwards, P. Bierman, J.D. Metzger and C. Lucht, 2005. Effects of vermicomposts produced from cattle manure, food waste and paper waste on the growth and yield of peppers in the field. Pedobiologia, 49(4): 297-306.

Awodun, M.A., L.I. Omonijo and S.O. Ojeniyi, 2007. Effect of goat dung and NPK fertilizer on soil and leaf nutrient content, growth and yield of pepper. International Journal of Soil Science, 2(2): 142-147.

Chapman, H.D. and P.F. Pratt, 1961. Methods of Analysis for Soil, Plant and Water Division of Agric. Sci., Calif. Univ.

Chaterjee, B., P. Ghanti, U. Thapa and P. Tripathy, 2005. Effect of organic nutrition in sport broccoli. Vegetable Science, 33(1): 51-54.

Chowdhury, R., 2004. Effects of chemical fertilizers on the surrounding environment and the alternative to the chemical fertilizers IES-ENVIS NEWSLETTER, 7(3): 4-5.

Cottenie, A., M. Verloo, L. Kiekers, G. Velghe and R. Camrbynek, 1982. Chemical Analysis of Plants and Soils. Hand Book, 1-63, Ghent, Belgium.

Dauda, S.N., F.A. Ajayi and E. Ndor, 2008. Growth and yield of water melon as affected by poultry manure application. J. Agric. Soc. Sci., 4: 121140. 
Dawa, K.K., H.M.E. Abd El-Nabi and W.M.E. Swelam, 2012. Response of sweet pepper plants (vegetative growth and leaf chemical constituents) to organic, biofertilizers and some foliar application treatments.J. Plant Production, Mansoura Univ., 3 (9):2465-2478.

Deepaa, N., C. Kaura, B. Singhb and H.C. Kapoorc, 2006. Antioxidant activity in some red sweet pepper cultivars. Journal of Food Composition and Analysis., 19(6-7): 572-578.

El-Sayed, S.F., 2006. Technology of Vegetable Production in Greenhouse and Low Tunnels. Egyptian Book Store, Cairo, Egypt.

Ewulo, B.S., K.O. Hassan and S.O. Ojeniyi, 2007.Comparative effect of cow dung manure on soil and leaf nutrient and yield of pepper. International Journal of Agricultural Research, 2(12): 1043-1048.

FAO (Food and Agriculture Organization), 1980.Soil and Plant Analysis.Soils Bulletin 38/2,250.

Fawzy Z.F., A.M. El-Bassiony, Li Yunsheng, Ouyang Zhu and A.A., Ghoname, 2012. Effect of mineral, organic and bio-N Fertilizers on growth, yield and fruit quality of sweet pepper. J. Appl. Sci. Res., 8(8): 3921-3933.

FiBL and IFOAM, 2014. The World of Organic Agriculture, Statistics and Emerging Trends.

Fiorentino, N. and M. Fagnano, 2011. Soil fertilization with composted solid waste: short term effects on lettuce production and mineral $\mathrm{N}$ availability. Geophysical Research Abstracts, Vol. 13, pp. 10520.

Geleta, L.F., M.T. Labuschagne and C.D. Viljoen, 2005. Genetic variability in pepper (Capsicum annuum L.) estimated by morphological data and amplified fragment length polymorphism markers. Biodiversity and Conservation, 14(10): 2361-2375.

Heeb, A., B. Lundegardh, G.P. Savage and T. Ericsson, 2006. Impact of organic and inorganic fertilizers on yield, taste, and nutritional quality of tomatoes. J. Plant Nut. Soil Sci., 169: 535-541.

Huez-Lopez, M.A., A.L. Ulery, Z. Samani, G. Picchioni and R.P. Flynn, 2011. Response of chile pepper to salt stress and organic and inorganic nitrogen sources: Growth and yield. Tropical and Subtropical Agroecosystems, 14(1): 137-147.

Liu, B., M.L. Gumpertz, S. Hu and J.B. Ristaino, 2007. Long-term effects of organic and synthetic soil fertility amendments on soil microbial communities and the development of southern blight. Soil Biol. Biochem., 39: 2302-2316.

Malgorzata, B. and K.Georgios, 2008. Physiological response and yield of pepper plants to organic fertilization. Journal of Central European Agriculture, 9(4): 715-722.

Masarirambi M.T., M.M. Hlawe, O.T. Oseni and T.E. Sibiya, 2010. Effects of organic fertilizers on growth, yield, quality and sensory evaluation of red lettuce Veneza Roxa. Agric. Biol. J. N. America, 1(6):1319-1324.

Ministry of Agriculture and Land Reclamation, 1988. Infrastructure and Irrigation Systems for Protected Crops. Bulletin No. 2: 51-57.

Ministry of Agriculture and Land Reclamation, Economic Affairs Sector (EAS), 2013. Bulletin of The Agriculture Statistics. 
Miyasaka, S., Y. Nakamura, H. Okamoto, 1997. Yield and nutrient absorption by lettuce by liming and fertilization mineral and organic soil. Brazilian Horticulture, 8(2): 6-9.

Naeem, M., J. lqbal and M.A.A. Bakhsh, 2006.Comparative study of inorganic fertilizers and organic manures on yield and yield components of Mungbean. J. Agric. Soc. Sci., 2: 227-239.

Nweke, I.A., S.I. Ijearu and D.N. Igili, 2013. Effect of different sources of animal wastes on the growth and yield of Okra in ustoxic dystropept at Enugu South Eastern, Nigeria.International Journal of Scientific and Technology Research, 2(3): 135-137.

Salama, G.M. and M.H. Zake, 2000. Fertilization with manures and their influence on sweet pepper of plastic-houses. Annals of Agricultural Science, Moshtohor, 38(2): 1075-1085.

Shehata, S.A., A.G. Behairy and Z.F. Fawzy, 2004. Effect of some organic manures on growth and chemical composition of sweet pepper grown in a sandy soil. Egyptian Journal of Agricultural Research, 82(2): 57-71.

Snedecor, G.W. and W.G. Cochran, 1980. Statistical methods. Sixth Edition, lowa state university press, Ames., lowa, USA.

Suge, J.K., M.E. Omunyin and E.N. Omami, 2011. Effect of organic and inorganic sources of fertilizer on growth, yield and fruit quality of eggplant (Solanum Melongena L). Arch. Appl. Sci. Res., 3(6): 470-479.

Suresh, K.D., G. Sneh, K.K. Krishn and C.M. Mool, 2004. Microbial biomass carbon and microbial activities of soils receiving chemical fertilizers and organic amendments. Archives Agron. Soil Sci., 50: 641-647.

Szafirowska, A. and K. Elkner, 2008. Yielding and fruit quality of three sweet pepper cultivars from organic and conventional cultivation. Vegetable Crops Research Bulletin, 69: 135-143.

Tonfack, L.B., A. Bernadac, E. Youmbi, V.P. Mbouapouognigni, M. Ngueguim and A. Akoa, 2009. Impact of organic and inorganic fertilizers on tomato vigor, yield and fruit composition under tropical andosol soil conditions. Fruits, 64: 167-177.

Watanabe, F.S. and S.R. Olsen, 1965. Test of an ascorbic acid method for determining phosphorus in water and $\mathrm{Na} \mathrm{HCO}_{3}$ extracts from soil. Soil Sci. Soc. Amer. Proc., 29: 677- 678.

Zayed, M.S., M.K.K. Hassanein, N.H. Esa and M.M.F. Abdallah, 2013. Productivity of pepper crop as affected by organic fertilizer, soil solarization, and endomycorrhizae. Annals of Agricultural Science 58(2): 131-137. 


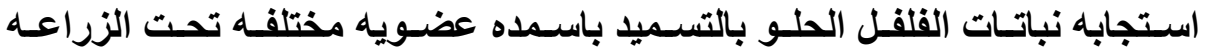

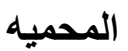

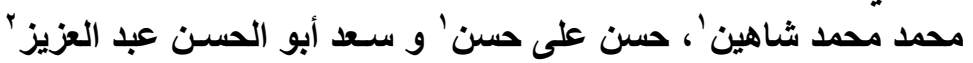

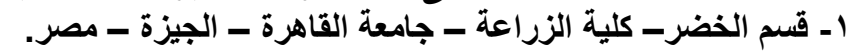

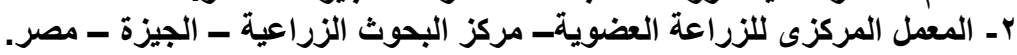

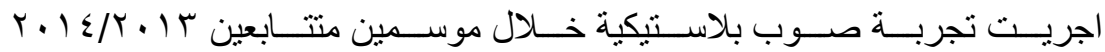

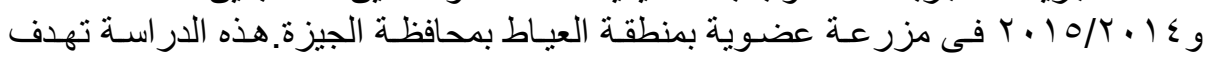

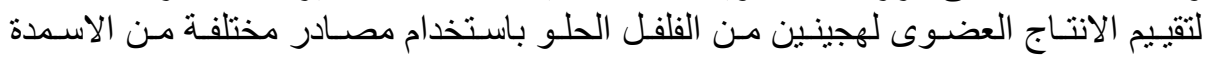

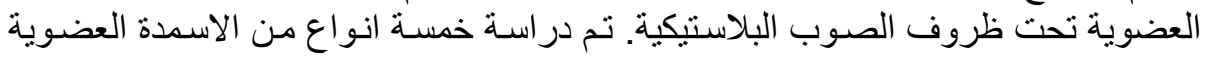

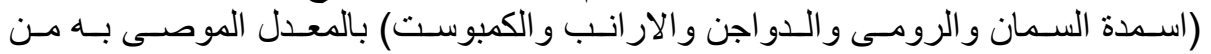

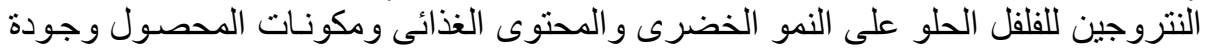

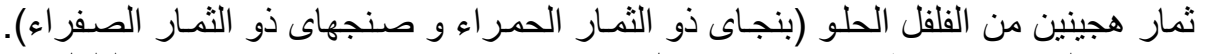

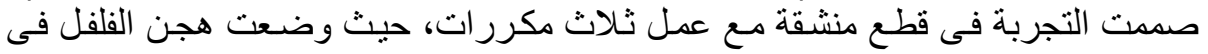

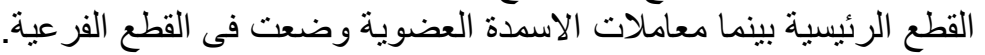

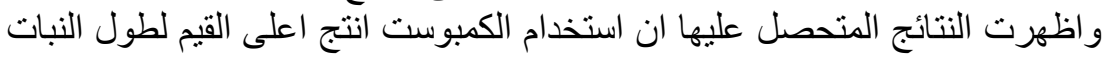

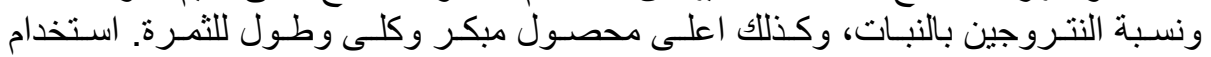

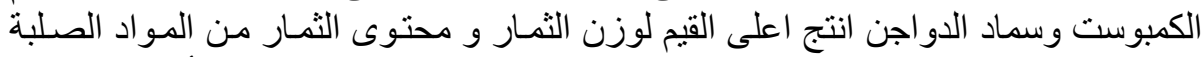

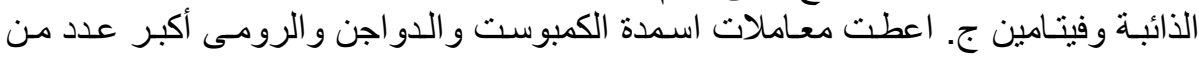

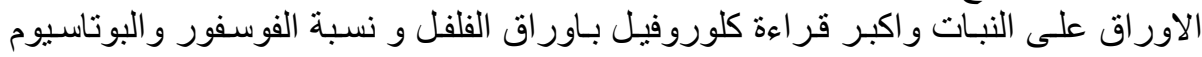

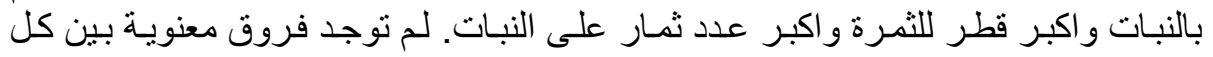

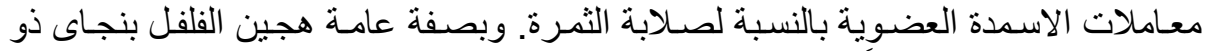

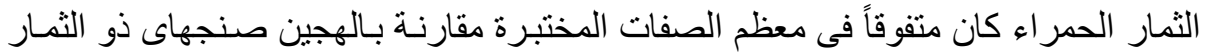

